\section{Petunia Growth and Maintenance in the Landscape as Influenced by Alternative Irrigation Strategies}

\author{
S.M. Scheiber ${ }^{1}$ and Richard C. Beeson, Jr. ${ }^{2}$ \\ Universityof Florida, Institute of Food and Agricultural Sciences, Environmental \\ Horticulture Department, MREC, 2725 Binion Road, Apopka, FL 32703
}

Additional index words. drainage lysimeter, landscape irrigation, tensiometer, manual watering, alternative irrigation methods, landscape water management, Petunia $\times$ hybrida

\begin{abstract}
Petunia $\times$ hybrida Vilm. 'Midnight' plants were grown in drainage lysimeters to evaluate growth in response to alternative irrigation strategies. Irrigation treatments were tensiometer-regulated automatic irrigation systems, regularly scheduled irrigation using an automated controller, and human perception of plant irrigation need (manual watering). Mean irrigation volumes were reduced by manual watering and tensiometerregulated treatments, compared to the automated controller. Total mean irrigation volume applied by the automated controller $(460 \mathrm{~L})$ was significantly greater than received by the manually watered $(293 \mathrm{~L})$ or tensiometer-regulated $(286 \mathrm{~L})$ treatments. Regularly scheduled irrigation using an automated controller resulted in higher assimilation rates, final shoot dry mass, final biomass, shoot to root ratios, and growth indices compared to other irrigation methods tested. Assimilation rates were significantly higher for tensiometer-controlled irrigation than the manually watered treatment, but no differences were reported between these two treatments for growth parameters. Visual observations indicated aesthetic quality was compromised among tensiometer-regulated and manually watered treatments relative to the automated controller treatment.
\end{abstract}

Continuing urban growth in the United States has resulted in landscape water consumption becoming prime target for water conservation (Salamone, 2002; Thayer, 1982). A recent survey of the landscape services industry reported that drought and water use restrictions were considered to be the primary threat for their industry (Hodges and Haydu, 2002). Over-irrigation in the urban environment, resulting from a lack of homeowner knowledge regarding plant water use needs and irrigation system operation, has been estimated to be $40 \%$ (Cotter and Chavez, 1979).

Landscape irrigation is usually applied by manual watering or via automated irrigation systems. Automatic systems are programmed with predetermined irrigation schedules based on days of the week, with little or no regard for soil moisture or plant water status. Furthermore, residential automated irrigation systems are rarely reprogrammed following initial installation, but reference evapotranspiration and correlated water requirements vary 2 - to 3 -fold between summer and winter seasons.

Automatic irrigation applications can be controlled by tensiometers that monitor soil moisture. Tensiometers are frequently used to control irrigation applications in vegetable fields and fruit orchards. Tensiometers have been used to a limited extent in the production of woody ornamentals and bedding plants; however, they have not been evaluated for

Received for publication 8 June 2005. Accepted for publication 28 Sept. 2005. This work supported by the Florida Agricultural Experiment Station, and approved for publication.

${ }^{1}$ Assistant professor and corresponding author; emailsmscheiber@ifas.ufl.edu.

${ }^{2}$ Associate professor. control of automated irrigation systems in urban landscapes. Where tensiometers have been used, irrigation water requirements were 2001). The objectives of this study were to 1 ) quantify petunia water usage when managed if flower beds can be maintained with reduced irrigation inputs without compromising aesthetic quality and plant health, and 3) determine whether reductions in supplemental flower bed irrigation can be achieved using tensiometer controlled automatic irrigation systems compared to traditional irrigation methods.

\section{Materials and Methods}

Petunia $\times$ hybrida Vilm. 'Midnight' were L containers and transplanted on 3 Feb. 2003 into drainage lysimeters made from 246-L rigid plastic containers (Lerio Corp., Kissimmee, Fla.) with a diameter of $0.89 \mathrm{~m}$ and a depth of $0.44 \mathrm{~m}$. Each lysimeter was located in an open-sided clear polyethylene covered shelter and contained six plants. Lysimeters were backfilled with native topsoil (Apopka fine sand) to simulate landscape conditions. Lysimeters were elevated $0.5 \mathrm{~m}$ above the soil line to facilitate drainage into tippingbucket rain gauges (model Rain Collector II; Davis Instruments Corp., Haywood, Calif.). The exterior of each plastic container was coated with white exterior latex flat house paint (Enterprise Paint Co., Wheeling, Ill.) to minimize the impact of solar radiation on root temperatures. Each lysimeter was managed using best management practices (Black and Gilman, 1998) except irrigation method. reduced by $25 \%$ to $40 \%$ (Lachurie and Lahaye, with various irrigation strategies, 2) determine obtained from a commercial nursery in 0.72
Controlled-release fertilizer was uniformly broadcast in each lysimeter immediately after transplanting with a standard $\mathrm{N}$ rate of 1.678 $\mathrm{kg} / 100 \mathrm{~m}^{-2}$ of $18 \mathrm{~N}-2.6 \mathrm{P}-9.9 \mathrm{~K}$ Osmocote (Scotts Co., Marysville, Ohio).

After transplanting, each lysimeter was irrigated at rate of $0.8 \mathrm{~cm}$ daily for $14 \mathrm{~d}$ then one of three irrigation methods was implemented: tensiometer-regulated automatic irrigation, regularly scheduled irrigation using an automated controller, and human perception of plant irrigation need. Following the establishment period, lysimeters irrigated by an automated controller received $0.8 \mathrm{~cm}$ daily. Tensiometerregulated lysimeters were irrigated back to field capacity when plant available water (2.5 $\mathrm{kPa}$ to $1.5 \mathrm{MPa}$; total of $21 \mathrm{cc} / 100 \mathrm{cc}$ soil) had declined to $\leq 50 \%$. Plant soil moisture availability was calculated from a soil water dehydration curve (Klute, 1986) and irrigation was controlled with tensiometers equipped with microswitches (model LTA-12; Irrometer Co., Inc., Riverside, Calif.) wired in series with an automated irrigation controller. Manual watering was applied by manual operation of the irrigation time clock.

Irrigation was applied within each lysimeter using three microirrigation spray stakes equipped with a half-circle spreader (model Stake 31; Spreader Red 180, Dan Sprinklers, Kibbutz Dan, Israel) situated in a triangular pattern with each emitter $46 \mathrm{~cm}$ apart and mounted $7.6 \mathrm{~cm}$ above ground level. The Christssen Coefficient of Uniformity was a minimum of 0.99 before planting (Haman et al., 1986). Irrigation of each lysimeter was controlled as a separate zone using an automated irrigation time clock (model Sterling 12; Superior Controls Co., Inc., Valencia, Calif.). Irrigations began at $0500 \mathrm{HR}$ and were completed by 0600 HR each day. Flow meters (model C700TP; ABS, Ocala, Fla.) were installed for each lysimeter to record irrigation volumes. Volume was recorded Monday through Friday.

Percolate. Daily percolate volumes were automatically recorded by tipping bucket rain gauges attached to a data logger (model CR-10; Campbell Scientific, Inc., Logan, Utah). Daily climatic data, including reference evapotranspiration (ET), was obtained from the Florida Automated Weather Station (FAWN) located $50 \mathrm{~m}$ from the site. Actual evapotranspiration $\left(\mathrm{ET}_{\mathrm{A}}\right)$ was calculated for each lysimeter as the difference between applied and percolate volumes. Water use efficiency (WUE) was calculated for each lysimeter as total biomass and total shoot dry mass, respectively, divided by cumulative $\mathrm{ET}_{\mathrm{A}}$.

Growth indexes and biomass. Measurements of average canopy height, widest canopy width, and width perpendicular to the widest width were recorded to calculate growth indexes as volume (growth index $=$ height $\times$ width $1 \times$ width 2 ). All plants were measured immediately after transplanting and at the termination of the experiment prior to harvest. To calculate root to shoot ratios, shoots were severed at the soil line and dried at $65^{\circ} \mathrm{C}$ until constant dry mass was obtained. To obtain root dry mass, each lysimeter was subsampled such that the center most plant and $1 / 6$ of the 
surrounding soil volume was removed. Soil was removed from the roots, and roots were dried as described for shoots. Total root mass was calculated by multiplying measured root mass by 6 .

Leaf gas exchange measurements. Gas exchange measurements were taken at 1000 , 1300, and 1600 HR for 5 consecutive days over 2 successive weeks. Measurements were taken on one full sun, recently mature leaf randomly selected in each lysimeter during each sampling recorded with a portable infrared gas analyzer (LCI Portable Photosynthesis System; ADC BioScientific Ltd., Hoddesdon, Herts, U.K.).

Aesthetic quality. Overall plant quality, plant density, and flower coverage, based on aesthetic appearance, were rated on a scale of 1 (dead) to 5 (mounded, proportional form; dense; complete coverage).

Data analysis. The experiment was conducted as a randomized complete block design with four blocks of single lysimeter replicates. Daily cumulative assimilation and daily cumulative transpiration were calculated for each lysimeter in a manner consistent with the calculation of water stress intervals (Beeson, 1992; Schulze et al., 1980). In brief, areas under curves generated from daily assimilation and transpiration rates were integrated, assuming both photosynthesis and transpiration were zero at dawn and sunset. Changes in rates between measurements were also assumed to be linear between one point to the next.

Growth data, consisting of plant height, growth index, shoot dry mass, root dry mass, total biomass, and shoot to root ratio were analyzed as a one-way ANOVA, with three irrigation treatments and four replications. Cumulative percolate volume, overall plant quality, plant density, and flower coverage were analyzed using a one-way ANOVA. Cumulative assimilation and transpiration values were analyzed as repeated measures using a split plot design with irrigation treatment as the main plot and day as a subplot (Snedecor and Cochran, 1980). Stomatal conductance was analyzed as repeated measures using a splitsplit plot design with irrigation treatment as the main plot, day as a subplot, and time within day as the sub-subplot. Where significant differences were indicated, mean separation was by Fisher's protected least significance differences (F protected LSD) (Snedecor and Cochran, 1980). Linear regression analysis was used to compare leaf gas exchange parameters with $\mathrm{ET}_{\mathrm{o}}$, mean daily vapor pressure deficits (vpd) and daily incident solar radiation. All analysis was conducted using SAS (version 8.1, SAS Institute, Cary, NC).

\section{Results and Discussion}

Leafgas exchangemeasurements. Transpiration $(\mathrm{E})$ was significantly $(P \leq 0.05)$ affected by an interaction of irrigation treatment $\times$ day (Fig. 1A). Daily cumulative E ranged from 90.65 to $294.53,41.14$ to 207.49 , and 75.39 to $267.44 \mathrm{~mol} \cdot \mathrm{m}^{-2}$ for automatically controlled, manually watered, and tensiometer-regulated treatments, respectively. Lowest $\mathrm{E}$ rates were period. Leaf gas exchange measurements were recorded on 17 and 18 Apr. 2003 (Fig. 1A) and corresponded with daily $\mathrm{ET}_{\mathrm{o}}$ and total incident radiation exceeding $0.5 \mathrm{~cm}$ and $2500 \mathrm{~kW} \cdot \mathrm{m}^{-2}$, respectively (Fig. 2A and B).

Daily cumulative assimilation rate (A) was significantly $(P \leq 0.05)$ affected by irrigation method or by day, but the interaction was not significant $(P \leq 0.05)$. Lysimeters receiving regularly scheduled irrigation from the automated controller had significantly higher $(P$ $\leq 0.05)$ daily mean cumulative assimilation rates $\left(0.63 \mathrm{~mol} \cdot \mathrm{m}^{-2}\right)$ compared to tensiometerregulated irrigation $\left(0.52 \mathrm{~mol} \cdot \mathrm{m}^{-2}\right)$, with both being higher $(P \leq 0.05)$ than the manually watered treatment $\left(0.44 \mathrm{~mol} \cdot \mathrm{m}^{-2}\right)$. Wang and Zhang (2004) reported decreased assimilation rates among Cucumis sativus $\mathrm{L}$. watered at $55 \%$ to $60 \%$ of field capacity versus well-irrigated controls. Tensiometer-based irrigation allowed soil dehydration to about $50 \%$ of field capacity, while manual watering was based
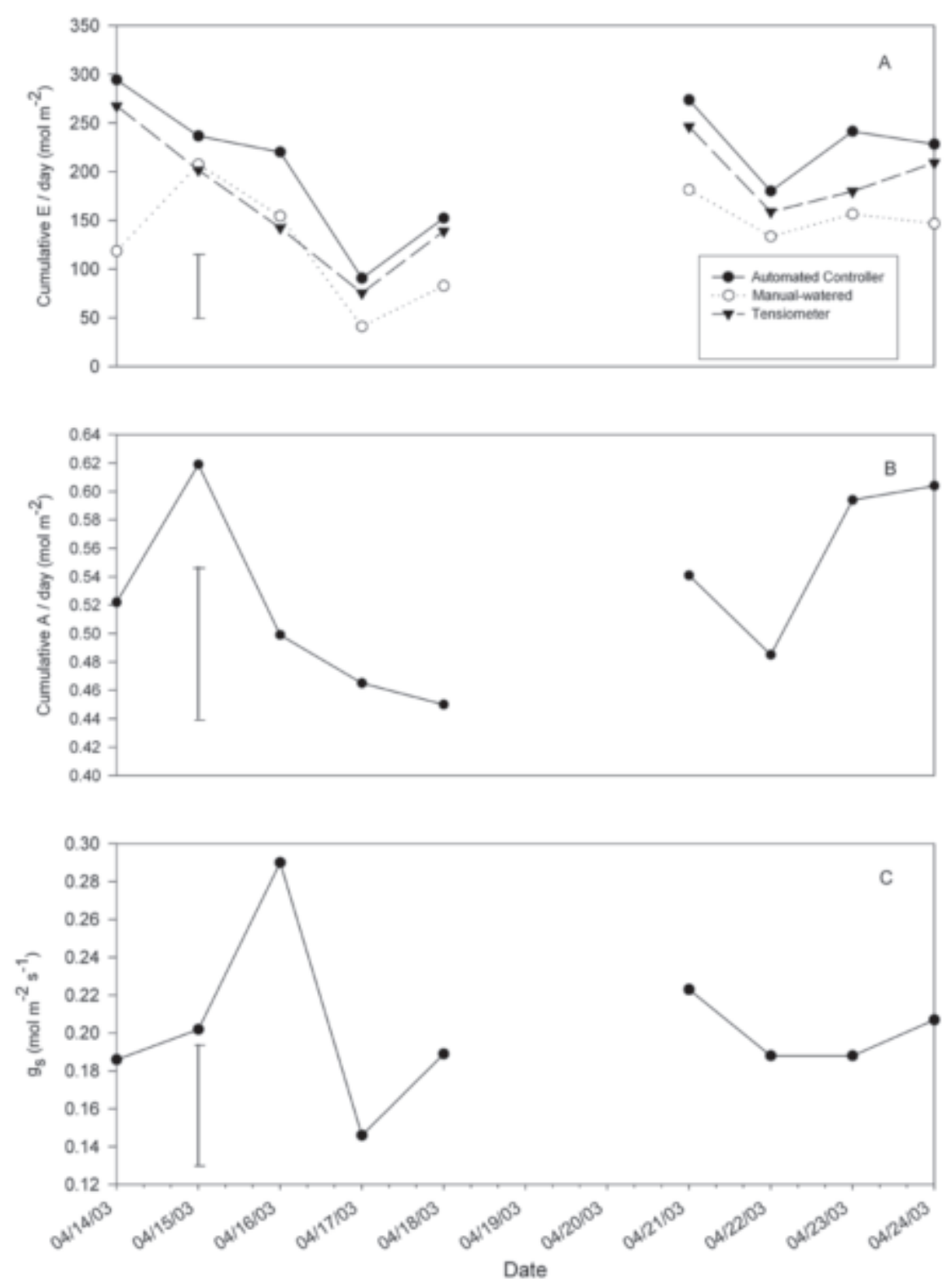

Fig. 1. (A) Daily cumulative transpiration (E) for each treatment, (B) daily cumulative assimilation (A), and $(\mathbf{C})$ daily mean stomatal conductance $(\mathrm{g})$ for the period of 14 to $24 \mathrm{Apr}$. 2003. The vertical bars represent the F test protected LSD at $\alpha=0.05$.

on human perception and thus applications were irregular and often infrequent. Daily cumulative assimilation rates averaged over treatments ranged between 0.45 and 0.62 $\mathrm{mol} \cdot \mathrm{m}^{-2}$ (Fig. 1B). Like values for E (Fig. 1A), lowest daily assimilation rates were recorded on 17 and 18 Apr.

Stomatal conductance $\left(\mathrm{g}_{\mathrm{s}}\right)$ was only affected $(P \leq 0.01)$ by sampling day, with no differences $(P>0.05)$ among irrigation treatments, hour of observation, or possible interactions. Mean $\mathrm{g}_{\mathrm{s}}$ ranged from 0.15 to $0.29 \mathrm{~mol} \cdot \mathrm{m}^{-2}$ over the 2-week sampling period with lowest rates again occurring on 17 and 18 Apr. 2003 (Fig. 1C). Trends were similar to those observed for both $\mathrm{E}$ and $\mathrm{A}$. Regression analysis of gas exchange parameters compared to environmental measurements of daily ET, total incident radiation, and mean vpd (Fig. 2) were consistently significant $(P \leq 0.05)$ only for $\mathrm{ET}_{\mathrm{o}}$ and inversely proportional. Although significant, 
$r^{2}$ values were very low, ranging from 0.027 for $\mathrm{ET}_{\mathrm{o}}$ versus A, to $r^{2}=0.212$ for $\mathrm{ET}_{\mathrm{o}}$ versus E for automatic controlled treatments (data not shown). This indicates partial stomatal closure occurred on days of relatively high evaporative atmospheric conditions to limit leaf gas exchange independent of irrigation treatments (Fig 2A, B, and C) and explains the statistical effect of day in the leaf gas exchange analysis.

Biomass and leachate. Consistent irrigation from the automated controller resulted in significantly greater biomass $(P \leq 0.05)$ than that achieved by the other two irrigation treatments (Table 1). Regularly scheduled irrigation resulted in $32 \%$ and $34 \%$ greater average shoot dry mass compared with tensiometer-regulated or manually watered treatments, respectively. Similar decreases in shoot dry mass in response to suboptimum irrigation were reported for Pentas lanceolata Schum.
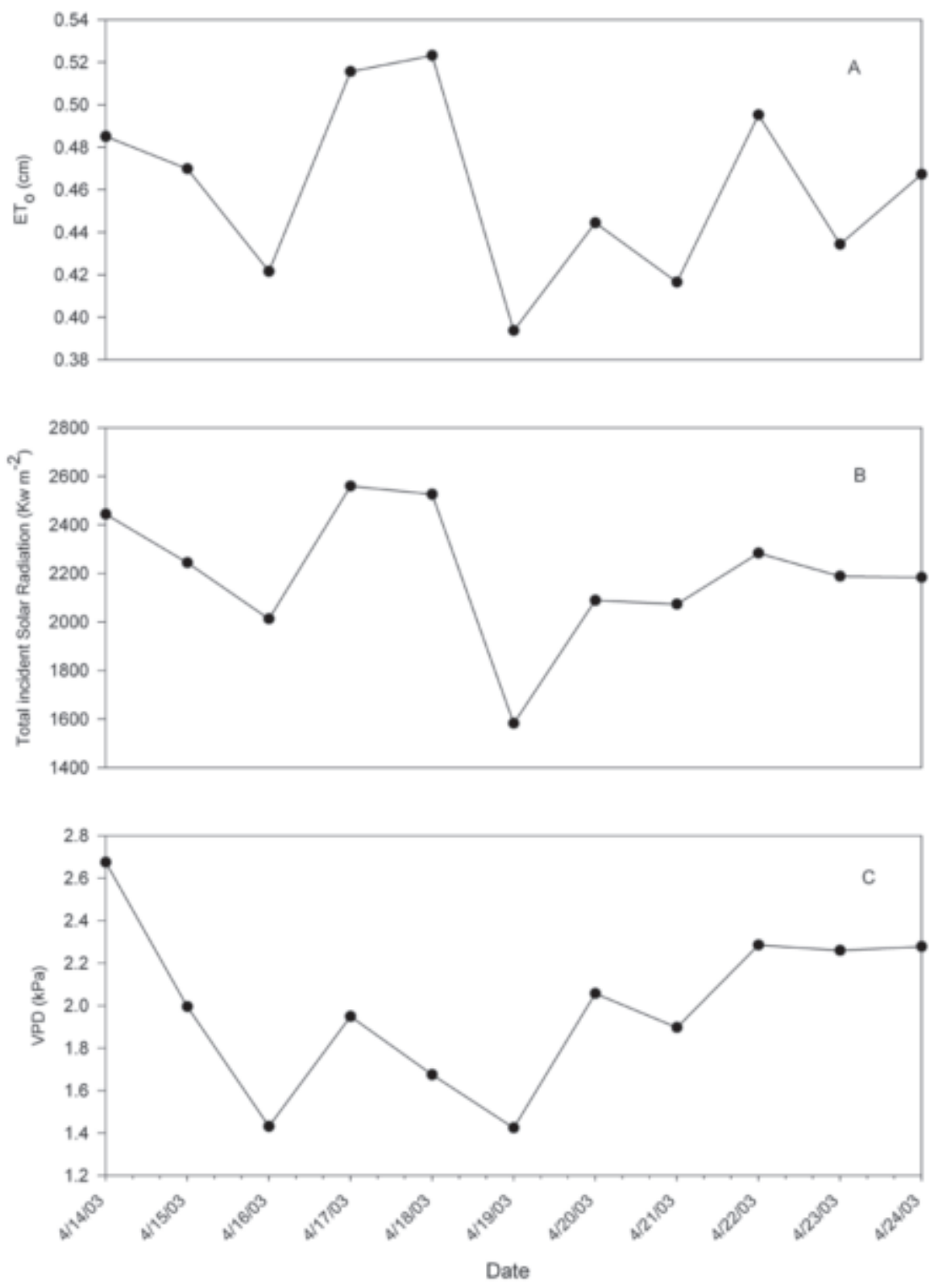

Fig. 2 (A) Daily reference evapotranspiration, ET, (B) total incident radiation average, and (C) vapor pressure deficits (VPDs) for the period of 14 to 24 Apr. 2003.
(Klock-Moore and Broschat, 2001). However, Klock-Moore and Broschat (1999) reported no differences in shoot dry mass of subirrigated or hand-watered Petunia $\times$ hybrida 'Ultra Red' despite significant differences in total irrigation volumes applied. Average root dry mass of Petunia $\times$ hybrida here was not influenced by irrigation method (data not shown). Mean total biomass increased $128 \%$ and $139 \%$ with automated control compared to tensiometer and manually watered treatments, respectively (Table 1). Shoot to root ratios increased by 1.7-fold with the automated controller relative to other irrigation strategies (Table 1). It has long been shown that decreases in soil water availability are correlated with decreases in shoot:root ratio in herbaceous plants (Harris, 1914). Both manually watered and tensiometer controlled treatments decreased canopy volume by about $28 \%$ (Table 1 ). There were no differences $(P>0.05)$ among parameters

\section{.} siometer-regulated treatments, respectively, to $0.599 \mathrm{~g} \cdot \mathrm{L}^{-1}$ for the automated controller. Total biomass WUE ranged from $2.28 \mathrm{~g} \cdot \mathrm{L}^{-1}$ for the automated controller to 8.95 and $13.85 \mathrm{~g} \cdot \mathrm{L}^{-1}$ for manually watered and tensiometer-regulated treatments, respectively, though differences were not significant $(P>0.05)$.

Cumulative irrigation volume was 2.8 -fold lower $(P \leq 0.0001)$ for both tensiometerregulated and manually watered treatments, compared to the automated controller, once irrigation treatments began following a 15-d establishment period after transplanting (Table $2)$. Mean leachate volumes were substantially increased $(P \leq 0.0001)$ with the automated controller compared to the other methods (Table 2). In practice, irrigation of both manually watered and tensiometer-regulated lysimeters normally occurred days apart. As a result, cumulative actual evapotranspiration $\left(\mathrm{ET}_{\mathrm{A}}\right)$ decreased by approximately $100 \%$ for both the manually watered and tensiometer-regulated treatments compared to the automated controller(Table 2). Furthermore, irrigation efficiency increased $(P$ $\leq 0.0001$ ) from $72 \%$ for the automated controller treatment to near $100 \%$ for the manually watered and tensiometer-regulated treatments, respectively (Table 2 ).

Although manual watering and tensiometers resulted in significant decreases in applied irrigation volumes, significant reductions in canopy size, biomass and assimilation rates also occurred.Agglelides et al. (1999) and Smajstrla and Locascio (1996) reported similar results for Lactuca sativa $\mathrm{L}$. and Lycopersicon esculentum Mill.yields, respectively. Using tensiometers to apply irrigation at varying soil water potentials, both studies reported that yields decreased as plant available water declined. However, these results differ from those reported for other vegetable species and many woody species. Ells et al. (1989) reduced applied irrigation volumes by $30 \%$ with tensiometers without compromising Cucumis sativus yield. Oki et al. (2001) and Huslig et al. (1993) reported significant reductions in irrigation volumes in the production of Rosa hybrida L. 'Kardinal' 
Table 1. Growth measurements for petunias irrigated with three strategies (automated controller, manual watering, tensiometers) over $90 \mathrm{~d}$ during early to late spring in central Florida.

\begin{tabular}{lcccc}
\hline & $\begin{array}{c}\text { Shoot } \\
\text { dry } \\
\text { mass }^{z}\end{array}$ & $\begin{array}{c}\text { Biomass } \\
(\mathrm{g})\end{array}$ & $\begin{array}{c}\text { Shoot to } \\
\operatorname{root}^{\mathrm{z}} \text { ratio } \\
(\mathrm{g})\end{array}$ & $\begin{array}{c}\text { Growth } \\
\text { index }^{\mathrm{y}} \\
\left(\mathrm{m}^{3}\right)\end{array}$ \\
Treatment & $305.40 \mathrm{a}^{\mathrm{x}}$ & $323.46 \mathrm{a}$ & $17.82 \mathrm{a}$ & $0.25 \mathrm{a}$ \\
Automated controller & $230.35 \mathrm{~b}$ & $253.27 \mathrm{~b}$ & $10.64 \mathrm{~b}$ & $0.18 \mathrm{~b}$ \\
Manual watering & $227.52 \mathrm{~b}$ & $249.27 \mathrm{~b}$ & $10.69 \mathrm{~b}$ & $0.18 \mathrm{~b}$ \\
Tensiometer & 0.0001 & 0.0001 & 0.0378 & 0.0017 \\
$P$ value & & & 0.001
\end{tabular}

${ }^{2}$ Means representative of four lysimeter replications based on six plants per lysimeter.

${ }^{\mathrm{y}}$ Growth index $=$ height $\times$ width $1 \times$ width 2 based on individual plant canopy.

${ }^{\times}$Mean separations within columns using Fisher protected LSD, $P=0.05$.

Table 2. Water balance for petunias over $75 \mathrm{~d}$ after implementation of three irrigation strategies (automated controller, manual watering, tensiometers) during early to late spring in central Florida. Each treatment was applied to a drainage lysimeter with a surface area of $0.62 \mathrm{~m}^{2}$ containing six plants each.

\begin{tabular}{lcccc}
\hline & $\begin{array}{c}\text { Cumulative } \\
\text { irrigation }\end{array}$ & $\begin{array}{c}\text { Leachate } \\
\text { vol }\end{array}$ & $\begin{array}{c}\text { Cumulative } \\
\mathrm{ET}_{\mathrm{A}}\end{array}$ & $\begin{array}{c}\text { Cumulative } \mathrm{ET}_{\mathrm{A}}{ }^{\prime} \\
\text { irrigation input } \\
(\%)\end{array}$ \\
Treatment & $(\mathrm{L})$ & $(\mathrm{L})$ & $186.7 \mathrm{a}$ & $0.72 \mathrm{~b}$ \\
Automated controller & $260.3 \mathrm{a}^{\mathrm{zy}}$ & $73.6 \mathrm{a}$ & $90.5 \mathrm{~b}$ & $0.98 \mathrm{a}$ \\
Manual watering & $93.4 \mathrm{~b}$ & $2.9 \mathrm{~b}$ & $88.5 \mathrm{~b}$ & $0.97 \mathrm{a}$ \\
Tensiometer & $90.7 \mathrm{~b}$ & $2.2 \mathrm{~b}$ & 0.0001 & 0.0001 \\
$P$ value & 0.0001 & 0.002 &
\end{tabular}

${ }^{2}$ Means representative of four lysimeter replications.

${ }^{y}$ Mean separations within columns using Fisher protected LSD, $P=0.05$.

Table 3. Overall plant quality, plant density, and flower coverage ratings for petunias irrigated with three strategies (automated controller, manual watering, tensiometers).

\begin{tabular}{lccc}
\hline Treatment & Quality & Density & $\begin{array}{c}\text { Flower } \\
\text { coverage }\end{array}$ \\
\hline Automated controller & $4.37 \mathrm{a}^{\text {zy }}$ & $4.25 \mathrm{a}$ & $4.56 \mathrm{a}$ \\
Manual watering & $2.94 \mathrm{~b}$ & $2.81 \mathrm{~b}$ & $3.06 \mathrm{~b}$ \\
Tensiometer & $3.25 \mathrm{~b}$ & $2.87 \mathrm{~b}$ & $3.19 \mathrm{~b}$ \\
$P$ value & 0.0018 & 0.0019 & 0.0103 \\
\hline
\end{tabular}

${ }^{2}$ Means representative of four lysimeter replications.

yMean separations within columns using Fisher's protected LSD, $P=0.05$.

and Prunus persica (L.) Batsch. 'Cresthaven', respectively, using tensiometer-regulated irrigation systems without quality or growth reductions compared to controls.

Visual observations of aesthetic quality revealed noticeable differences among treatments, with tensiometer and manually watered treatments showing the greatest negative response $(P \leq 0.01)$ due to reduced irrigation volumes (Table 3$)$. Reductions in quality were marked by decreased floral displays and declines in plant density. Flohr and Conover (1995) reported similar decreased flowering of Petunia $\times$ hybrida 'Rose Madness' during production with reduced irrigation frequency. Shoot mass is directly and tightly correlated with $\mathrm{ET}_{\mathrm{A}}$ (Arkey, 1963). Reductions in canopy density were likely due to decreased branching or branch length attributed to limited turgor pressure and restricted A. While A was comparable among treatments based on gas exchange data taken near the end of the experiment, A was based on extrapolated values of near instantaneous measurements. Biomass production however, integrates water availability for transpiration through tight coupling with photosynthesis, with favorable meteorological conditions and nutrients for growth. Given equivalent climatic and nutrient conditions in this study, reduced biomass signifies restrictions in water availability. In the current study, tensiometer-regulated lysimeters were irrigated to field capacity when plant available water had declined to $\leq 50 \%$. Based on aesthetic attributes, this was too dry. Additional research is needed to determine if acceptable landscape standards for bedding plants can be obtained through tensiometer-regulated irrigation set to irrigate with a smaller deficits in plant available water.

\section{Literature Cited}

Agglelides, S., I. Asimakopoulos, P. Kerkides, and A. Skondras. 1999. Effects of soil water potential on the nitrate content and yield of lettuce. Commun. Soil Sci. Plant Anal. 30:235-243.

Arkey, R.J. 1963. Relationships between plant growth and transpiration. Hilgardia 34:559-584.

Beeson, R.C. 1992. Restricting overhead irrigation to dawn limits growth incontainer-grown woody ornamentals. HortScience 27:996-999.

Black, R.J. and E.J.Gilman. 1998. Your Florida guide to bedding plants: Selection, establishment, and maintenance. Univ. Press Fla., Gainesville.

Cotter, D.J. and F. Chavez. 1979. Factors affecting water application rates on urban landscapes. J. Amer. Soc. Hort. Sci. 104:189-191.

Ells, J.E., E.G. Kruse, and A.E. McSay. 1989. Scheduling irrigation for cucumbers. HortScience 24:448-452.

Flohr, R.C. and C.A. Conover. 1995. Production and postproduction watering schedule effects on plant growth, quality and blooming of pansies and petunias. Proc. Fla. State Hort. Soc. 107:414-416.

Haman, D.Z., A. Smaljstra, and D. Pitt. 1996. Uniformity of sprinkler and microirrigation systems for nurseries. Univ. Fla. IFAS Coop. Ext. Serv. Bul. 321

Harris, F.S. 1914. The effect of soil moisture, plant food, and age on the ratio of tops toroots in plants. J. Amer. Soc. Agron. 6:65-75.

Hodges, A.W. and J.J. Haydu. 2002. Economic impacts of the Florida environmental horticulture industry, 2000. Univ. Fla. IFAS Econ. Rpt. El 02-3.

Huslig, S.M., M.W. Smith, and G.H. Brusewitz. 1993. Irrigation schedules and annual ryegrass as a ground cover to conserve water and control peach tree growth. HortScience 28:908-913.

Klock-Moore, K.A. and T.K. Broschat. 1999. Differences in bedding plant growth and nitrate loss with a controlled-release fertilizer and two irrigation systems. HortTechnology 9:206-209.

Klock-Moore, K.A. and T.K. Broschat. 2001. Effect of four growing substrates on growth of ornamental plants in two irrigation systems. HortTechnology 11:456-460.

Klute,A. 1986. Water retention: Laboratory methods, p. 635-662. In; A. Klute (ed). Methods of soil analysis. Part 1. Physical and mineralogical methods. 2nd ed. ASA-SSSA Agron. Monogr. 9.

Lachurie, J. and D. Lahaye. 2001. Automatization of irrigation in outdoor nurseries based on the monitoring of moisture in substrate. PHM-Revue-Horticole 422:26-30.

Oki, L.R., J.H. Lieth, and S. Tjosvold. 2001. Irrigation of Rosa hybrida L. 'Kardinal' based on soil moisture tension increases productivity and flower quality. Acta Hort. 547:213-219.

Salamone, D. 2002. A drying oasis series: Florida water crisis, p. 1. chapter 1. Orlando Sentinel.

SAS Institute. 1990. SAS user's guide: Statistics. 6th ed. SAS Inst., Cary, N.C.

Schulze, E.D., A.E. Hall, O.L. Lange, M. Evenari, L. Kappen, and U. Buschbom. 1980. Long-term effects of drought on wild and cultivated plants in the Negev desert. I. Maximal rates of net photosynthesis. Oecologia 45:11-18.

Smajstrla, A.G. and S.J. Locascio. 1996. Tensiometer-regulated, drip-irrigation of tomato. Appl Eng. Agr. 12:315-319.

Snedecor and Cochran. 1980. Statistical methods. 7 th ed. Iowa State Univ. Press, Ames.

Thayer, R.L. 1982. Public response to water-conserving landscapes. HortScience 17:562-565.

van Iersel, M.W. and K.S. Nemali. 2004. Drought stress can produce small but compact marigolds. HortScience 39:1298-1301.

Wang, S. and F. Zhang. 2004. Effect of different water treatments on photosynthesis characteristics and leaf ultrastructure of cucumber growing in solar greenhouse. Acta Hort. 633:397-401. 